\title{
The Effectiveness of Using A Cloud-Based Application in Developing Speaking and Critical Thinking Skills of English Major Students at Faculty of Education
}

\author{
Amal Ahmed Mostafa El-Zayat
}

\begin{abstract}
The present study aimed at investigating the effectiveness of Voice Thread in developing speaking and critical thinking skills of English major students at Faculty of Education. A total of 30 EFL second year students enrolled in English Department at the Faculty of Education, Mansoura University participated in the study which involved one group experimental design. Instruments designed and used were an EFL speaking checklist; critical thinking Checklist; speaking and critical thinking test; rubrics for scoring speaking and critical thinking skills and an interview. Activities based on the use of VoiceThread were carried out by the study group. The results of the statistical analysis showed that there was a significant development in students' EFL speaking and critical thinking skills. Consequently, using VoiceThread proved to be effective in developing students' EFL speaking and critical thinking skills.
\end{abstract}

Keywords: VoiceThread (VT), EFL Speaking Skills, Critical Thinking skills.

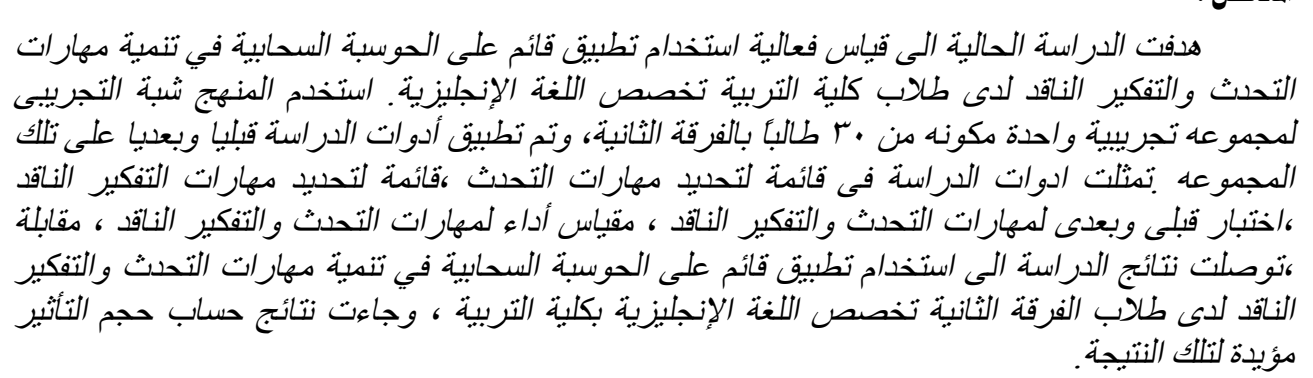

\section{Introduction:}

The rapid expansion of technology in everyday life led individuals and institutions to integrate technology into education for teaching and learning purposes. Using technology in educational fields serves as a great shift in presenting knowledge and information in an enjoyable environment. Students are surrounded by the World Wide Web, applications, and online learning management systems. Therefore, it is recommended to employ these tools for developing students' language skills and for enhancing higher order thinking skills in higher education.

Learners often evaluate their success in language learning as well as the effectiveness of their English course on the basis of how much they feel they have improved in their spoken language proficiency 
(Richards, 2008). Speaking is an interactive process of constructing meaning that involves receiving, processing information and producing.

Boonkit (2010) indicated that instructors regularly ask the question why most of undergraduate students are unable to speak English confidently, especially for communication in authentic situations with international speakers. Oradee (2012) stated that in foreign language teaching and learning, ability to speak is the most difficult and required still as long as it is the main way of communications.

Speaking is a crucial part of second and foreign language learning and teaching. Still, Susanti (2007) clarified that despite the importance of teaching speaking, it has been underestimated where English language teachers still teaching speaking in forms of memorizing dialogue and repeating drills. However, educators assert that the main target of teaching speaking should be developing learners' communication skills, as in that way, learners can learn how to communicate and express themselves appropriately. In the same line, many researchers found that students suffer from their speaking skills' deficiency (Aliakbari \& Jamalvandi 2010; Aljumah, 2011; Diyyab, Abdel-Haq \& Aly 2013; Mohammed, 2013).

Higher order thinking skills like critical thinking, creative thinking and problem solving are considered necessary skills for $21 \mathrm{st}$ century individuals. However, technology competency as the effective use of the internet and its services and learning online are also skills necessary for the new generation. Although online teaching is not a new trend in the education fields, few researches dealt with implementing instructional techniques and strategies within the virtual environment and implying these implementations for developing critical thinking skills. (Kalelioğl \& Gülbahar, 2012). According to Yusuf and Adeoye (2012) critical thinkers are not only analyzing, interpreting and evaluating information, they analyze also assumptions and inferences made about that information. They are also raising crucial problems and questions, formulating them obviously, gathering and assessing relevant information, using abstracts concepts, thinking open mindedly and communicating with others effectively.

In a survey conducted by Asgharheidari and Tahriri (2015) on 30 EFL teachers, they believed that it is a crucial role of being a teacher is to increase learners' critical thought. They added that the relation between speaking and critical thinking skills is dynamic; communication is a dynamic interactive process that implies the effective interaction of ideas, facts, values and feeling. Based on this idea, critical thinking has an effect on all types of communications as speaking, writing, reading and listening. Teachers can enhance both communication skills and critical thinking (CT) alongside in every 
activity with learners in the classroom.

According to Shirkhani and Fahim (2011) the integration of critical thinking (CT) into the EFL courses is significant for many reasons. If language learners are responsible for their own thinking, they can evaluate and monitor their own techniques of learning in a successful way. So, critical thinking raises learners' experience of learning process and provides a meaningful language.There is a high degree of correlation between critical thinking and the achievements of learners. Language development and thinking are closely integrated and according to Brown (2004), the aim of a perfect language program should go beyond the linguistic factors and seek to improve CT skills among language students. Language teachers have a vital part in enhancing critical thinking skills among students.

For any foreign language learning Voice tools, particularly, are essential prerequisites; they urge language learners to practice and to improve their speaking skills out the classroom with providing feedback on their performance. Similarly, through using voice tools learners can communicate using the target language and they can practice or exercise in different times and from different locations while enhancing their reflective thinking skills and learning autonomy needed for their future careers (Pop, Tomuletiu \& David, 2011).
According to Kidd and Chen, (2009) Voice Thread is the most stimulating approaches to online collaborative environment. Voice Thread is a free instrument that helps multiple users to interact with one another asynchronously using different modalities, such as audio, video files, text, microphone or telephone. Voice Thread is used widely in both $\mathrm{K}-12$ and higher education (Pacansky-Brock, 2015). Instructors are using Voice Thread in several disciplines and fields from mathematics and science to languages, art, and humanities. Educators and learners can employ Voice Thread to display course content; Identify, compare, and provide feedback; teach language skills and vocabulary; and provide critique and commentary on topics and ideas (Chan, Pallapu, 2012).

Voice thread (VT) is one of the best tools available to instructors and learners as it assist users to communicate and collaborate around different topics. VT makes learners come alive because they are given a platform to express their thoughts and it lets users to type texts and record audio comments about images or other external links. Voice threading involves learners to enhance the skills that active critical thinkers process during the learning experience (Muttaqin, 2014).

Related studies to Voice Thread and its effectiveness:

Ataeifar and Bagheri (2017) conducted a study to examine the integration of the Web 2.0 
technology, namely, Voicethread as a new elicitation technique to specify if this asynchronous voice-conferencing instrument can be an appropriate technique to asses speaking skill. Fifteen EFL learners participated in the study at Zand Higher Education Institute in Iran. Data was collected through numerical results and it was analyzed. The findings indicated that Voice thread was rated as a good and successful elicitation technique for EFL learners' speaking skills.

Ghoneim and Abdelsalam (2016) investigated the effectiveness of using Voice Thread on developing EFL pre-service teachers' speaking skills. Thirty EFL fourth year undergraduates students in the Faculty of Education, Menoufia University participated in the study. The design of the study involved one intact group experimental design. The instrument used was a pre-post test to assess speaking skills of the participants. The treatment group was involved in VoiceThread activities. The results concluded that using voice thread had a great effect in improving EFL speaking skills of student teachers.

Taddei and Budhai (2015) described the impact of using voicerecorded reflections through utilizing Voice Thread on cognitive presence of pre-service teachers in a hybrid course and its effect on critical thinking and deeper learning. Participants who involved in a project for service-learning during improving other skills essential to become a professional teacher. Data was collected through using a survey that was assigned to evaluate critical thinking and learning. The responses of students to voice-recorded reflections were analyzed. The findings highlighted the use of reflection helped in developing the growing professional.

Lepore (2014) studied students' motivation to improve pronunciation skills during participating in conversations. Participants were joined in a French course where they concentrate on pronunciation skills through Voice Thread. Instruments used were questionnaires, students continuously self-reported, journal entries, and assessment activities. Results concluded that learners had more positive views of performance on pronunciation exercises and also higher second language selfconfidence campaigned with pronunciation. In addition, results indicated that participating in Voice Thread involves students to be aware of their development in pronunciation. So, creating an environment that support feedback improves pronunciation as well as selfmotivation.

In a qualitative study Blomberg (2013) reported on how students acquire vocabulary words when required to form Voice Thread publication. The participants were third-grade students. Data in the current study were gathered through using videotaped observation/ transcription, field notes, pre-post test. The main finding of the study showed that Voice Thread is a successful moderate for stimulating talk and 
conversation about vocabulary words and for improving students' vocabulary acquisition.

Herlihy and Pottage (2013) aimed at investigating the impact of using web 2.0 tools as a mean of formative speaking assessment of students studying English for academic purposes at Swinburne University and their engagement. Utilizing Voice Thread to create an authentic environment for communication where teachers and students can access to recordings of other students. It was found that Voice Thread provided a good basis for developing formative assessment speaking activities. Also, students showed incremental development in their speaking skills.

Dunn (2012) examined the effect of an asynchronous VoiceThread on the anxiety and oral proficiency of high school members studying Spanish as a foreign language. The research utilized a quasi experimental design where the treatment group used VoiceThread for developing their speaking skills. The control group employed the traditional method of the language laboratory for practicing speaking. The instruments used were The Anxiety Scale for measuring anxiety levels and an analytical grading rubric to measure students' oral proficiency. Results indicated no significant for the anxiety scale. While, results yielded a significant main effect variance between the controll and experiimental groups in the oral proficiency data.
Pop, Tomuletiu and David (2011) highlighted the importance of asynchronous web2.0 voice instruments: Voxopop (VoP) and Voice Thread (VT) in improving EFL speaking practice. Qualitative data was deriven and analyzed from the participants who were sixty-two first year university students. Opinions were gathered through employing VoP interviews as well as classical interviews at the end of semester. Results indicated that students established more positive trends towards speaking and a significant increase confidence while speaking.

McCormack (2010) interrogated the use of Voice Thread for reflecting and reviewing on collaborative learning experiences. Twenty five teacher candidates took part in semistructured interviews. Data was collected through using case study method and interview. The findings of this study concluded that using Voice Thread assignments improved student reflective, Web technology literacy, response and engagement. The results pointed out that participants considered Voice Thread easy to use and a fairly rapid process and that their learning outcomes were improved. The teacher candidates also proposed some pedagogical advantages such as motivation, supporting higher-order thinking and facilitating learnfing in areas of speaking, listening and reflecting.

\section{Statement of the problem:}

Based on the Literature review and the results of the pilot study, students seem to lack some necessary 
speaking and critical thinking skills. So, there is a need to develop EFL student teachers' speaking and critical thinking skills. Therefore, the current study seeks to investigate the effectiveness of using VoiceThread a cloud- based application in developing speaking and critical thinking skills of English Major Students at the Faculties of Education.

\section{Questions of the study:}

The current study attempted to answer the following main question:

"What is the effectiveness of using Voice Thread for developing speaking and critical thinking skills of EFL Major student teachers at the Faculties of Education?"

For research purposes, this main question is subdivided into the following questions:

1. What are the EFL speaking skills necessary for second year student teachers at the faculty of Education?

2. What are the EFL critical thinking skills necessary for second year student teachers at the faculty of Education?

3. What are the features of a cloudbased application; namely Voice Thread?

4. What is the effectiveness of using Voice Thread for developing EFL speaking skills of second year student teachers at the Faculties of Education?

5. What is the effectiveness of using Voice Thread for developing EFL critical thinking of second year student teachers at the Faculties of Education?

\section{Purposes of the study:}

The study aimed at:

1- Assessing the current level of the EFL speaking and critical thinking skills of the second year English Major student teachers at the Faculty of Education.

2- Investigating effectiveness of using Voice Thread in developing EFL speaking skills of English Major student teachers at the Faculties of Education.

3- Investigating the effectiveness of using Voice Thread in developing critical thinking of English Major student teachers at the Faculties of Education.

\section{Significance of the study:}

It is hoped that the study could contribute to:

1- Developing EFL speaking and critical thinking skills among English Major student teacher.

2- Enriching literature concerning effectiveness of using Voice Thread in developing EFL speaking and critical thinking skills of English Major student teachers at the Faculties of Education.

3- Paving the way for other researchers to investigate the possibility of integrating Voice Thread in enhancing teacher education program.

\section{Delimitations of the study:}

This study was delimited to:

- A sample of second year English Major student teachers at the Department of Foreign Language, 
Faculty of Education, Mansoura University.

- Some EFL Speaking skills including: pronunciation, fluency, grammar, vocabulary and comprehensibility required for English Major student teacher at Faculty of Education, Mansoura University

- Some EFL Critical Thinking skills including: analysis and evaluation required for English Major student teachers at Faculty of Education, Mansoura University.

\section{Study hypotheses:}

The hypotheses of the study were as follows:

1- There is a statistically significant difference between the mean scores of the experimental group students on the pre-post administration of the speaking and critical thinking skills test in favor of the post-one.

2- There is a statistically significant difference between the mean scores of the experimental group students on the pre and post administration of the Speaking Skills Test in favor of the post-one.

3- There is a statistically significant difference between the mean scores of the experimental group students on the pre-post administration of the EFL critical thinking skills Test in favor of the post-one.

4- There is a correlation at $(0.05)$ between speaking skills and critical thinking skills of the experimental group students.

\section{Methods of the study: \\ Participants:}

Participants of the study consisted of thirty $(\mathrm{N}=30)$ second year English Major student teachers at the Department of Foreign Languages, Faculty of Education, Mansoura University.

\section{Instruments of the study:}

The following instruments were used in the study:

- A speaking skills questionnaire to determine the essential speaking skills required for English Major second year student teachers.

- A critical thinking questionnaire to determine the essential critical thinking skills required for English Major second year student teachers.

- A pre-post speaking and critical thinking skills test to measure students' level.

- A scoring rubric to assess speaking skills.

- A scoring rubric to assess critical thinking skills.

- An interview to collect students" opinion on VoiceThread effectivity.

\section{Design of the study:}

The present study adopted the quasi-experimental design .The design utilized in this study is one experimental group that consisted of thirty second year English Major student teachers at the Department of Foreign Languages, Faculty of Education, Mansoura University 
Procedures of the study:

The study proceeded as follows:

1- Reviewing literature, previous studies related to VoiceThread, speaking and critical thinking skills in order to set the theoretical background of the study.

2- Designing a speaking skills questionnaire to determine the essential skills required for English Major second year student teachers.

3- Designing a critical thinking questionnaire to determine the essential skills required for English Major second year student teachers.

4- Designing a test to measure students' speaking and critical thinking skills.

5- Designing a rubric for scoring the speaking test dimensions.

6- Designing a rubric for scoring critical thinking skills test dimensions.

7- Designing the activities that would be used in VoiceThread.

8- Presenting the instruments of the study to a group of jurors for validation.

9- Modifying the instruments according to jurors' opinions.

10- Measuring the instruments' reliability.

11- Selecting a sample of English Major student teachers at the faculty of Education, English Language Department for the experimental group.
12- Administering the study instruments on the treatment group (pre-administration).

13-Conducting the proposed treatment using Voic Thread application.

14- Administering the study instruments after applying Voice Thread activities to the experimental group (Postadministration).

15- Analyzing and interpreting the data and presenting results.

16- Providing Summary, conclusion, and recommendations for further research.

The following section provides a description of the instruments in detail.

\section{The checklist}

Aim:

A list of speaking and critical thinking sub skills was presented in the form of a checklist to EFL professors for determining the most important skills needed for EFL second year major students to be included in the program.

\section{Source of the checklist}

The speaking skills included in the checklist were derived from different sources. Reviewing literature related to the area of speaking skills and sub-skills. For the critical thinking skills, they were derived from (Facione, 1990) and his classification of critical thinking skills. 


\section{Description of the checklist}

The EFL speaking skills checklist consisted of five main skills of pronunciation; vocabulary; grammar; fluency and comprehensibility. Concerning the critical thinking skills checklist, it consisted of seven main skills (interpretation; analysis; evaluation; inference; explanation; reflection and self-regulation.

\section{Validity of the checklist}

The speaking and critical thinking skills checklists were submitted to jury members; Specialists and professors in the field of EFL and methods of teaching and staff members at the Department of English.

After analyzing the jury responses, the skills that had the highest percentage, i.e. were agreed upon at least $75 \%$ or more by jury members were selected. So based on the jury members' feedback, five speaking sub-skills are important for students to master and two main subskills of critical thinking should be included in the study namely; analysis and evaluation.

\section{The Test}

\section{Aim:}

The test was designed to measure students' EFL speaking and critical thinking skills before being exposed to the Voice Thread application and their improvement, if any after using it.

\section{Sources of the Test:}

The test was developed in the light of the following resources:
- Reviewing previous studies concerned with language tests, especially those assessing speaking skills.

- Reviewing TOEFL and IELTS sample tests.

\section{Description:}

The test consisted of seven questions. The seven questions measure the speaking skills and subskills (pronunciation; vocabulary; grammar; fluency and comprehensibility) and the critical thinking skills and sub-skills (analysis and evaluation). Some questions are adopted from the TOEFL and IELTS sample tests. The test was scored through a scoring rubric. The first question is concerned with measuring students' pronunciation skills where students are given a short passage to read aloud. Questions two, three and four are to measure students' speaking sub-skills (pronunciation; vocabulary; grammar; fluency and comprehensibility) and analysis skills. While Questions five, six and seven are to measure students' speaking subskills (pronunciation; vocabulary; grammar; fluency and comprehensibility) and evaluation skills.

\section{Validity of the test}

To measure the validity of the test, it was submitted to a group of jurors of TEFL professors at some Egyptian Universities to validate the test. According to the comments of the jurors, some test items were deleted, others were modified and 
additional items for testing analysis and evaluation skills were added.

\section{Reliability of the test}

To measure test reliability, the researcher administered the test to a group of second year English Department students at Mansoura
Faculty of Education in the first week of the second term of the academic year 2016- 2017. In order to determine the reliability of the Test, the researcher used Cronbach's Alpha as indicated in Table 1:

Table 1 Alpha Cronbach for the reliability of the test

\begin{tabular}{|c|c|c|c|c|c|}
\hline Main Skills of Test & N & Mean & Std. deviation & Variance & Cronbach's Alpha \\
\hline Pronunciation & 7 & 20.75 & 3.768 & 14.197 & 0.862 \\
\hline Fluency & 6 & 13.80 & 3.778 & 14.274 & 0.828 \\
\hline Grammar & 6 & 14.45 & 3.78 & 14.261 & 0.762 \\
\hline Vocabulary & 6 & 18.50 & 2.646 & 7.000 & 0.743 \\
\hline Comprehensibility & 6 & 17.15 & 3.216 & 10.34 & 0.810 \\
\hline Analysis & 3 & 7.65 & 1.981 & 3.924 & 0.799 \\
\hline Evaluation & 3 & 7.95 & 1.986 & 3.945 & 0.744 \\
\hline Total & $\mathbf{3 7}$ & $\mathbf{1 0 0 . 2 5}$ & $\mathbf{1 3 . 6 4 5}$ & $\mathbf{1 8 6 . 1 9 7}$ & $\mathbf{0 . 7 9 3}$ \\
\hline
\end{tabular}

Table 1 indicated that the Alpha Cronbach value 0.793 for the test and that all the values are significant at 0.05 level. According to the data gathered, the test is considered highly reliable.

\section{Rubric}

\section{Aim}

The rubrics prepared by the researcher were constructed to assess the performance of students' speaking and critical thinking skills during the pre-post-test.

\section{Source}

The rubrics in this study were derived from reviewing the literature related to the evaluation of speaking and critical thinking Skill.

\section{Description}

The rubric for correcting the EFL speaking test consists of five sub-skills of speaking; pronunciation; vocabulary; grammar; fluency and comprehensibility. There are four indicators for each subs-kill ranging from 4 marks to 1 mar; 1) Poor speaker 2) Satisfactory speaker 3) Good speaker 4) Advanced speaker.

The second rubric is used for scoring critical thinking skills. It consisted of two main skills; analysis and evaluation. There are four indicators for each sub-skill to evaluate students' performance ranging from 4 marks to 1 mark; 1) No knowledge 2) Emerging 3) Proficient 4) Mastery

\section{Validity:}

To measure the validity of the two rubrics, they were submitted to specialized jurors of TEFL professors and staff members at some of the Egyptian universities to validate them. The rubrics were modified according to the jurors' opinion. The speaking 
and the critical thinking rubric proved to be valid.

\section{Content of Voice Thread}

Speaking and critical thinking activities for the experimental group were held via Voice Thread which is an asynchronous cloud-based application that helps learners to communicate through posting voice recordings to a web page using cell phones or microphones to record their voices from a mobile phone or computer or Laptop. The speaking activities created for the study covered relevant topics of students' interests.

\section{1- Orientation Sessions}

In the orientation phase, learners were provided with training which covers the course curriculum, learning outcomes, method of delivery, and testing procedures. Preparation of the learners included training them on tools included in the Voice Thread and student registration. Students were introduced to Voice Thread and were taught how to make an initial post and how to comment and reply to their classmate. They were provided with sample Voice Threads to realize how the forum looked after many posts had been made. They practiced how to post audio and video comments. They were also trained to post comments using headsets with microphones.

\section{Voice Thread Implementation}

Students created their own accounts and were asked to have a username and a password to access the account. It was the hardest part as some students found it difficult to remember their e-mails. Voice Thread provides a solution for that problem as students can have access with the same e-mail and the same account but with different identities. The researcher asked students to record their comments to the image or question.

Videos, pictures, and songs for student commentary were uploaded to Voice Thread. Participants received a copy of the weekly activity instruction sheet. This sheet contained the questions and any resources students used for speaking practice. They were able to finish posting their comments on the weekly speaking activities from their home computers, cell phones, i-pads, school computers, or any device with Internet access.

\section{Post- testing}

After experimentation, participants were post tested to verify the use of Voice Thread.

\section{Results and Discussion:}

The following hypotheses were tested:

\section{The First Hypothesis}

The first hypothesis states that" There is a statistically significant difference between the mean scores of the experimental group students on the pre-post administration of the speaking skills test in favor of postone".

In order to verify this hypothesis, the t-test was used to compare the scores of the study to identify the significant differences between the mean scores on the pre- 
and the post administration of the speaking skills test. The results in table 2 presents the students' mean scores, standard deviation, $\mathrm{t}$-value and level of significance of the study sample in the post assessment of the overall speaking skills.

Table 2: " $t$ " test results comparing the mean scores of the experimental group of the pre-post application of the EFL Speaking skills

\begin{tabular}{|c|c|c|c|c|c|c|c|}
\hline Skills & Measuring & N. & Mean & $\begin{array}{c}\text { Std. } \\
\text { Deviation }\end{array}$ & T-Value & Df & Sig. \\
\hline $\begin{array}{c}\text { Speaking } \\
\text { Skills }\end{array}$ & Pre & 30 & 42 & 8.64 & 10.42 & 29 & Significant \\
\hline & Post & 30 & 76.87 & 10.19 & & & \\
\hline
\end{tabular}

As shown in Table 2 t-value is (10.42) which is significant at the (0.05) level of significance. Moreover, the mean score of the preadministration is $(\mathrm{M}=8.64)$ while that of the post administration is $(M=10.19)$. The development of the speaking skills may be due to the use of Voice Thread. Thus, the hypothesis was accepted and this shows that there are statistically significant differences between the mean scores of the experimental group students on the pre-post administration of the EFL speaking skills in favor of post-one.

In order to determine the effect size of the Voice Thread activities in enhancing the Speaking skills for English major students, the eta squared ( $\eta 2)$ was calculated in table 3 .

Table 3: Value of ( $\eta 2)$ and the effect size of the treatment in developing the Speaking skills

\begin{tabular}{|c|c|c|c|}
\hline Skill & T- Value & Partial Eta Square & Effect Size \\
\hline Speaking Skills & 10.42 & 0.79 & Large \\
\hline
\end{tabular}

Table 3 represents the effect size of using Voicce Thread on the overall speaking skills of the experimental group students where eta square value is (0.79) that reflects a high effect. This large effect size for the overall speaking skills indicated that $79 \%$ of the variance in the students' speaking skills could be attributed to the experimental treatment. This reflects that the Voice Thread is effective in developing participants' EFL speaking skills.
The hypothesis has the following sub-hypotheses:

\section{The First hypothesis:}

The first hypothesis states that "There is a statistically significant differences between the mean scores of the experimental group students on the pre-post application of the EFL Pronunciation skills in favor of postone".

In order to verify this hypothesis, the t-test was used to compare the scores of the study to 
identify the significant differences between the mean scores on the preand the post administration of the Pronunciation skills. The results in table 4 presents the students' mean scores, standard deviation, $\mathrm{t}$-value and level of significance of the study sample in the post assessment of the pronunciation skills.

Table $4:$ : $t$ " test results comparing the mean scores of the experimental group of the pre-post application of the EFL pronunciation skills

\begin{tabular}{|c|c|c|c|c|c|c|c|}
\hline Skill & Measuring & N. & Mean & Std. Deviation & T- Value & Df & Sig. \\
\hline $\begin{array}{c}\text { Pronunciatio } \\
\text { n }\end{array}$ & Pre & 30 & 9.73 & 2.88 & 10.55 & 29 & Significant \\
\hline & Post & 30 & 18.10 & 3.58 & & & \\
\hline
\end{tabular}

As shown in Table 4 that $\mathrm{t}$ value is $(10.55)$ which is significant at the (0.05) level of significance. Moreover, the mean score of the pre administration is $(\mathrm{M}=9.73)$ while that of the post administration is $(\mathrm{M}=18.10)$. The development of the pronunciation skills may be due to the use of Voice Thread. Thus, the hypothesis was accepted and this shows that there are statistically significant differences between the

Table 5: Value of ( $\eta 2)$ and the effect size of the treatment in developing the pronunciation skills

\begin{tabular}{|c|c|c|c|}
\hline Skill & T- Value & Partial Eta Square & Effect Size \\
\hline Pronunciation & 10.55 & 0.79 & Large \\
\hline
\end{tabular}

Table 5 represents the effect size of using Voicce Thread on pronunciation skills of the experimental group students where eta square value is (0.79) that reflects a high effect. This large effect size for the pronunciation skills indicates that $79 \%$ of the variance in the students' speaking skills could be attributed to the experimental treatment. This reflects that the Voice Thread is mean scores of the experimental group students on the pre-post administration of the EFL Pronunciation skills in favor of postone.

In order to determine the effect size of the Voice Thread activities in enhancing the pronunciation skills for English major students, the eta squared ( $\eta 2$ ) was calculated in table 5 . effective in developing participants' EFL pronunciation skills.

\section{The Second hypothesis:}

The second hypothesis states that "There is a statistically significant difference between the mean scores of the experimental group students on the pre-post application of the EFL fluency skills in favor of post-one".

In order to verify this hypothesis, the t-test was used to 
compare the scores of the study to identify the significant differences between the mean scores on the preand the post administration of the fluency skills test. The results in table
6 presents the students' mean scores, standard deviation, $\mathrm{t}$-value and level of significance of the study sample in the post assessment of the fluency skills.

Table 6: " $t$ " test results comparing the mean scores of the experimental group of the pre-post application of the EFL Fluency skills

\begin{tabular}{|c|c|c|c|c|c|c|c|}
\hline Skill & Measuring & N. & Mean & Std. Deviation & T- Value & df & Sig. \\
\hline Fluency & Pre & 30 & 8.30 & 2.07 & 9.55 & 29 & Significant \\
\hline & Post & 30 & 13.87 & 2.67 & & & \\
\hline
\end{tabular}

As shown in Table 6 that "There are statistically significant differences between the mean scores of the experimental group students on the pre-post administration of the EFL fluency skills in favor of post-one", where "t-value" is (9.55) which is significant at the (0.05) level of significance. Thus, the hypothesis was supported. The development of the pronunciation skills may be due to the use of the Voice Thread application.

In order to determine the effect size of the Voice Thread activities in enhancing the fluency skills for English major students, the eta squared ( $\eta 2)$ was calculated in table 7.

Table 7: Value of ( $\eta 2)$ and the effect size of the treatment in developing the pronunciation skills

\begin{tabular}{|c|c|c|c|}
\hline Skill & T- Value & Partial Eta Square & Effect Size \\
\hline Fluency & 9.554 & 0.76 & Large \\
\hline
\end{tabular}

Table 7 represents the effect size of using Voicce Thread on fluency skills of the experimental group students where eta square value is (0.76) that reflects a high effect. This large effect size for the fluency skills indicates that $76 \%$ of the variance in the students' speaking skills could be attributed to the experimental treatment. This reflects that the Voice Thread is effective in developing participants' EFL fluency skills.

\section{The Third Hypothesis}

The third hypothesis states that "There is a statistically significant difference between the mean scores of the experimental group students on the pre-post application of the EFL grammar skills in favor of post-one".

In order to verify this hypothesis, the t-test was used to compare the scores of the study to identify the significant differences between the mean scores on the preand the post administration of the grammar skills test. The results in table 8 presents the students' mean 
scores, standard deviation, $\mathrm{t}$-value and level of significance of the study sample in the post assessment of the grammar skills.

Table 8: " $t$ " test results comparing the mean scores of the experimental group of the pre-post application of the EFL grammar skills

\begin{tabular}{|c|c|c|c|c|c|c|c|}
\hline Skill & Measuring & N. & Mean & Std. Deviation & T- Value & Df & Sig. \\
\hline Grammar & Pre & 30 & 7.60 & 1.67 & 9.95 & 29 & Significant \\
\hline & Post & 30 & 13.93 & 2.88 & & & \\
\hline
\end{tabular}

As shown in Table 8 that $\mathrm{t}$ value is $(9.95)$ which is significant at the (0.05) level of significance. Moreover, the mean score of the pre administration is $(\mathrm{M}=7.60)$ while that of the post administration is $(\mathrm{M}=13.93)$. The development of the grammar skills may be due to the use of Voice Thread. Thus, the hypothesis was accepted and this shows that there are statistically significant differences between the mean scores of the experimental group students on the pre-post administration of the EFL grammar skills in favor of post-one.

In order to determine the effect size of the Voice Thread activities in enhancing the grammar skills for English major students, the eta squared ( $\eta 2)$ was calculated in table 9.

Table 9: Value of ( $\eta 2)$ and the effect size of the treatment in developing the grammar skills

\begin{tabular}{|c|c|c|c|}
\hline Skill & T- Value & Partial Eta Square & Effect Size \\
\hline Grammar & 9.95 & 0.77 & Large \\
\hline
\end{tabular}

Table 9 represents the effect size of using Voice Thread on grammar skills of the experimental group students where eta square value is $(0.77)$ that reflects a high effect. This large effect size for the grammar skills indicates that $77 \%$ of the variance in the students' speaking skills could be attributed to the experimental treatment. This reflects that the Voice Thread is effective in developing participants' EFL grammar skills.

\section{The Fourth Hypothesis}

The fourth hypothesis states that There is a statistically significant difference between the mean scores of the experimental group students on the pre-post application of the EFL vocabulary skills in favor of postone".

In order to verify this hypothesis, the t-test was used to compare the scores of the study to identify the significant differences between the mean scores on the preand the post administration of the vocabulary skills. The results in table 10 presents the students' mean scores, standard deviation, $\mathrm{t}$-value and level of significance of the study sample in the post assessment of the vocabulary skills. 
Table 10: " $t$ " test results comparing the mean scores of the experimental group of the pre-post application of the EFL vocabulary skills

\begin{tabular}{|c|c|c|c|c|c|c|c|}
\hline Skill & Measuring & N. & Mean & $\begin{array}{c}\text { Std. } \\
\text { Deviation }\end{array}$ & T-Value & Df & Sig. \\
\hline Vocabulary & Pre & 30 & 8.27 & 2.07 & 11.27 & 29 & Significant \\
\hline & Post & 30 & 14.93 & 2.98 & & & \\
\hline
\end{tabular}

As shown in Table 10 that $\mathrm{t}$ value is (11.27) which is significant at the (0.05) level of significance. Moreover, the mean score of the pre administration is $(\mathrm{M}=8.27)$ while that of the post administration is $(\mathrm{M}=14.93)$. The development of the vocabulary skills may be due to the use of Voice Thread. Thus, the hypothesis was accepted and this shows that there are statistically

significant differences between the mean scores of the experimental group students on the pre-post administration of the EFL vocabulary skills in favor of post-one.

In order to determine the effect size of the Voice Thread activities in enhancing the vocabulary skills for English major students, the eta squared $(\eta 2)$ was calculated in table 11.

Table 11:Value of ( $\eta 2)$ and the effect size of the treatment in developing the vocabulary skills

\begin{tabular}{|c|c|c|c|}
\hline Skill & T- Value & Partial Eta Square & Effect Size \\
\hline Vocabulary & 11.27 & 0.81 & Large \\
\hline
\end{tabular}

Table 11 represents the effect size of using Voicce Thread on vocabulary skills of the experimental group students where eta square value is $(0.81)$ that reflects a high effect. This large effect size for the vocabulary skills shows that $81 \%$ of the variance in the students' speaking skills could be attributed to the experimental treatment. This reflects that the Voice Thread is effective in developing participants' EFL vocabulary skills.

\section{The Fifth Hypothesis}

The fifth hypothesis states that There is a statistically significant difference between the mean scores of the experimental group students on the pre-post application of the EFL comprehensibility skills in favor of post-one.

In order to verify this hypothesis, the t-test was used to compare the scores of the study to identify the significant differences between the mean scores on the preand the post administration of the comprehensibility skills test. The results in table 12 presents the students' mean scores, standard deviation, $t$-value and level of significance of the study sample in the post assessment of the comprehensibility skills. 
Table 12: " $t$ " test results comparing the mean scores of the experimental group of the pre-post application of the EFL comprehensibility skills

\begin{tabular}{|c|c|c|c|c|c|c|c|}
\hline Skill & Measuring & N. & Mean & $\begin{array}{c}\text { Std. } \\
\text { Deviation }\end{array}$ & $\begin{array}{c}\text { T- } \\
\text { Value }\end{array}$ & df & Sig. \\
\hline Comprehensibility & Pre & 30 & 8.10 & 1.52 & 10.80 & 29 & Significant \\
\hline & Post & 30 & 16.03 & 3.61 & & & \\
\hline
\end{tabular}

As shown in Table 12 that $\mathrm{t}$ value is $(10.80)$ which is significant at the (0.05) level of significance. Moreover, the mean score of the pre administration is $(\mathrm{M}=8.10)$ while that of the post administration is $(\mathrm{M}=16.63)$. The development of the comprehensibility skills may be due to the use of VoiceThread. Thus, the hypothesis was accepted and this shows that there are statistically mean scores of the experimental group students on the pre-post administration of the EFL comprehensibility skills in favor of post-one.

In order to determine the effect size of the VoiceThread activities in enhancing the comprehensibility skills for English major students, the eta squared ( $\eta 2)$ was calculated in table 13. significant differences between the

Table 13: Value of ( $\eta 2)$ and the effect size of the treatment in developing the comprehensibility skills

\begin{tabular}{|c|c|c|c|}
\hline Skill & T- Value & Partial Eta Square & Effect Size \\
\hline Comprehensibility & 10.80 & 0.80 & Large \\
\hline
\end{tabular}

significant difference between the mean scores of the experimental group students on the pre-post application of the EFL critical thinking skills in favor of post-one.

In order to verify this hypothesis, the t-test was used to compare the scores of the study to identify the significant differences between the mean scores on the preand the post administration of the critical thinking skills. The results in table 14 presents the students' mean scores, standard deviation, $\mathrm{t}$-value and level of significance of the study sample in the post assessment of the critical thinking skills.

Table 13 represents the effect size of using VoicceThread on comprehensibility skills of the experimental group students where eta square value is $(0.81)$ that reflects a high effect. This large effect size for the comprehensibility skills indicates that $81 \%$ of the variance in the students' speaking skills could be attributed to the experimental treatment. This reflects that the VoiceThread is effective in developing participants' EFL comprehensibility skills.

\section{The Second Hypothesis}

The second main hypothesis states that There is a statistically 
Table 14: "t" test results comparing the mean scores of the experimental group of the pre-post application of the EFL critical thinking skills

\begin{tabular}{|c|c|c|c|c|c|c|c|}
\hline Skills & Measuring & N. & Mean & Std. Deviation & T- Value & Df & Sig. \\
\hline Critical Thinking & Pre & 30 & 6.67 & 1.40 & 11.36 & 29 & Significant \\
\hline & Post & 30 & 14.23 & 2.94 & & & \\
\hline
\end{tabular}

As shown in Table 14 that $t$ value is (11.36) which is significant at the $(0.05)$ level of significance. Moreover, the mean score of the pre administration is $(\mathrm{M}=6.67)$ while that of the post administration is $(\mathrm{M}=14.23)$. The development of the critical thinking skills may be due to the use of VoiceThread. Thus, the hypothesis was accepted and this shows that there are statistically significant differences between the mean scores of the experimental group students on the pre-post administration of the EFL critical thinking skills in favor of post-one.

In order to determine the effect size of the VoiceThread activities in enhancing the critical thinking skills for English major students, the eta squared ( $\eta 2)$ was calculated in table 15.

Table 15: Value of ( $\eta 2)$ and the effect size of the treatment in developing the critical thinking skills

\begin{tabular}{|c|c|c|c|}
\hline Skills & T- Value & Partial Eta Square & Effect Size \\
\hline Critical Thinking Skills & 11.36 & 0.82 & Large \\
\hline
\end{tabular}

Table 15 represents the effect size of using VoicceThread on critical thinking skills of the experimental group students where eta square value is (0.82) that reflects a high effect. This large effect size for the critical thinking skills indicates that $82 \%$ of the variance in the students' speaking skills could be attributed to the experimental treatment. This reflects that the VoiceThread is effective in developing participants' critical thinking skills.

The hypothesis has the following sub-hypotheses:

\section{The First Hypothesis}

The first hypothesis states that difference between the mean scores of the experimental group students on the pre-post application of the EFL analysis skills in favor of post-one".

In order to verify this hypothesis, the t-test was used to compare the scores of the study to identify the significant differences between the mean scores on the preand the post administration of the analysis skills test. The results in table 16 presents the students' mean scores, standard deviation, $\mathrm{t}$-value and level of significance of the study sample in the post assessment of the analysis skills. 
Table $16: " t "$ test results comparing the mean scores of the experimental group of the pre-post application of the EFL analysis skills

\begin{tabular}{|c|c|c|c|c|c|c|c|}
\hline Skill & Measuring & N. & Mean & Std. Deviation & T-Value & Df & Sig. \\
\hline Analysis & Pre & 30 & 3.40 & 0.86 & 11.58 & 29 & Significant \\
\hline & Post & 30 & 6.90 & 1.65 & & & \\
\hline
\end{tabular}

As shown in Table 16 that $\mathrm{t}$ value is (11.58) which is significant at the (0.05) level of significance. Moreover, the mean score of the pre administration is $(\mathrm{M}=3.40)$ while that of the post administration is $(\mathrm{M}=6.90)$. The development of the analysis skills may be due to the use of VoiceThread. Thus, the hypothesis was accepted and this shows that there are statistically significant differences

between the mean scores of the experimental group students on the pre-post administration of the EFL analysis in favor of post-one.

In order to determine the effect size of the VoiceThread activities in enhancing the analysis skills for English major students, the eta squared $(\eta 2)$ was calculated in Table 17.

Table 17: Value of ( $\eta 2)$ and the effect size of the treatment in developing the analysis skills

\begin{tabular}{|c|c|c|c|}
\hline Skill & T- Value & Partial Eta Square & Effect Size \\
\hline Analysis & 11.578 & 0.82 & Large \\
\hline
\end{tabular}

Table 17 represents the effect size of using VoicceThread on analysis skills of the experimental group students where eta square value is (0.82) that reflects a high effect. This large effect size for the analysis skills indicates that $82 \%$ of the variance in the students' speaking skills could be attributed to the experimental treatment. This reflects that the VoiceThread is effective in developing participants' analysis skills.

\section{The Second Hypothesis}

The second hypothesis states that "There is a statistically significant difference between the mean scores of the experimental group students on the pre-post application of the EFL evaluation skills in favor of post-one".

In order to verify this hypothesis, the t-test was used to compare the scores of the study to identify the significant differences between the mean scores on the preand the post administration of the evaluation skills test. The results in table 18 presents the students' mean scores, standard deviation, $\mathrm{t}$-value and level of significance of the study sample in the post assessment of the evaluation skills. 
Table 18: " $t$ " test results comparing the mean scores of the experimental group of the pre-post application of the EFL evaluation skills

\begin{tabular}{|c|c|c|c|c|c|c|c|}
\hline Skill & Measuring & N. & Mean & Std. Deviation & T- Value & Df & Sig. \\
\hline Evaluation & Pre & 30 & 3.27 & 0.64 & 11.14 & 29 & Significant \\
\hline & Post & 30 & 7.33 & 2.02 & & & \\
\hline
\end{tabular}

As shown in Table 18 that $\mathrm{t}$ value is (11.14) which is significant at the $(0.05)$ level of significance. Moreover, the mean score of the pre administration is $(\mathrm{M}=3.27)$ while that of the post administration is $(\mathrm{M}=7.33)$. The development of the analysis skills may be due to the use of VoiceThread. Thus, the hypothesis was accepted and this shows that there between the mean scores of the experimental group students on the pre-post administration of the EFL analysis in favor of post-one.

In order to determine the effect size of the VoiceThread activities in enhancing the evaluation skills for English major students, the eta squared $(\eta 2)$ was calculated in table 19. are statistically significant differences

Table 19: Value of ( $\eta 2)$ and the effect size of the treatment in developing the evaluation skills

\begin{tabular}{|c|c|c|c|}
\hline Skill & T- Value & Partial Eta Square & Effect Size \\
\hline Evaluation & 11.143 & 0.81 & Large \\
\hline
\end{tabular}

\section{The Third Hypothesis}

The third hypothesis states that "There is a correlation at (0.05) between speaking skills and critical thinking skills of the experimental group students".

In order to test this hypothesis, Spearman's rank correlation coefficient was used to identify the relation between speaking skills and critical thinking skills of the experimental group students. The results of the t-test are presented in table 20 .
Table 19 represents the effect size of using VoicceThread on evaluation skills of the experimental group students where eta square value is (0.81) that reflects a high effect. This large effect size for the evaluation skills indicates that $81 \%$ of the variance in the students' speaking skills could be attributed to the experimental treatment. This reflects that the VoiceThread is effective in developing participants' evaluation skills. 
Table 20: Correlation Coefficient between the speaking skills and critical thinking skills of the experimental group students.

\begin{tabular}{|c|c|c|}
\hline Variables & Speaking Skills & Critical thinking Skills \\
\hline Speaking Skills & 1 & \\
\hline Critical thinking Skills & $0.823^{* *}$ & 1 \\
\hline
\end{tabular}

$(* *)$ : Sig at 0.01

Table 20 shows that there is a correlation which is significant at the (0.01) level of significance between speaking and critical thinking skills of the experimental group students.

\section{Discussing the Results}

These high percentages reflect student teachers' positive attitudes towards Voice Thread. The ones who engaged in using Voice Thread experienced a new learning situation where they were intrinsically motivated to learn and to play an active role in their own learning. That is why they perceived the application as a good and successful experience. Moreover, they perceived the content of the application as relevant with appropriate sequence. Consequently, it can be concluded that the program was a success according to student's points of view.

\section{These findings might be due to the following:}

1. The nature of the Voice Thread emphasizes the communicative competence based on the desire to develop the ability of language learners to interact and understand meaning in real life contexts, rather memorizing language forms.
2. Voice Thread provides a less threatening environment needed for learners to practice speaking and critical thinking skills through using the target language.

3. In the current study, students had the opportunity to practice their speaking skills in an environment without feeling shy or fearing of negative comments from the instructor. Learners in the present study have the chance to post comments asynchronously from the faculty or at their leisure time or at home where they might feel more comfortable and less pressured than being surrounded by their colleagues.

4. Students have the time to think of different topics to search for information from different sources on the Internet, consequently, to practice and develop their critical thinking skills.

5. Students discussed topics relevant to their interests that arouses their thinking and promote them to use and employ appropriate vocabulary related to the topics being discussed.

6. Materials are presented in different way videos, audios, documents and instructor's explanation, all these elements 
arouses students' interaction and understanding of the content of the program.

7. Social interaction is a key element for the experimental group as students were asked to express their opinions and to respond individually, then they are asked to exchange information and to complete stories with their colleagues.

8. The attractive framework of Voice Thread where students are involved in interesting activities.

To sum up, the results of the present study are consistent with the results of the studies conducted by, Ataeifar and Bagheri (2017), Ghoneim and Abdelsalam (2016). Lepore (2014), Blomberg (2013), Herlihy and Pottage (2013), Dunn (2012), and Pop, Tomuletiu and David (2011) in that they proved the effectiveness of Voice Thread in developing speaking skills and subskills. The results of the present study are also in accordance with the results of the studies that handled the Voice Thread and critical thinking skills. These include the studies conducted by Taddei and Budhai (2015), Augustsson (2010), and McCormack (2010). Moreover, the findings of the present study affirm the assumption underlying other studies, that speaking skills improved in an enjoyable and encouraging context

Based on the above-mentioned analysis of the data, it can be concluded that the cloud based application namely, voicethread was effective in improving student teacher's speaking skill in general, and its sub-skills; pronunciation, grammar, vocabulary, fluency and comprehensibility. In addition, it was proved that Voice Thread was effective in improving student teacher's critical thinking skill in general, and its sub-skills; analysis and evaluation

\section{Descriptive Analysis}

The qualitative Results were conducted using the data obtained from the interview. The main aim of the interview was identifying the students' reactions and comments to their learning through Voice Thread. It took place after the students were given the last post-test. A sample of students was interviewed. Each interview lasts between three to five minutes. While interviewing, a taperecorder was used to ensure the interview process and ease review process.

The students were asked about how they feel about using Voice Thread. The question that was addresses to students:

"How can you evaluate your experience with using Voice Thread, the advantages and disadvantages?"

Most of the students had positive feelings of Voice Thread. Students said that they like Voice Thread because they are encouraged to practice and improve English speaking skill and critical thinking skills. Voice Thread was easy to use and also interesting and enjoyable. 
Here are some of the results during the students' interview:

\section{Student (A):}

"It was a distinguished experience as it was the first time for me to speak in English freely without being afraid of making mistakes.

\section{Student (B):}

"It was a little bit difficult for me at the beginning, but after experiencing more than one session, I started to remember old words that I forgot because of the little practice.

\section{Student (C):}

"I love practicing English and that was my chance. It was amazing except for the bad internet connection. I enjoyed using the website because it helps me to think and speak English freely without being shy."

According to the findings, it can be concluded that voicethread had positive effects on the improvement of students' speaking and critical thinking skills. Students are motivated, engaged and interested in voicethread.

\section{Conclusion:}

The above findings make it clear that the proposed treatment was effective in improving second year student teachers' speaking and critical thinking skills. This may be attributed to Voice Thread application combining various speaking and critical thinking activities. In addition the cooperative supportive environment that was enriched with various tools.

\section{Recommendations}

Based on the results and conclusions of the study, the following recommendations are suggested:

1. Voice Thread is recommended to be used as a framework for developing speaking and critical thinking skills and it can be adapted to develop other language skills.

2. Voice Thread is recommended to be integrated in the "speaking Course" that student teachers study at Mansoura Faculty of Education.

3. More attention should be paid for integrating critical thinking skills in different language skills in an enjoyable way.

4. Faculty of Education Professors should train pre-service EFL teachers on the use of Voice Thread in teaching speaking and critical thinking skills.

\section{Suggestions for Further Research}

The following suggestions are recommended to be considered for further research:

1.To use Voice Thread for developing other language skills than speaking.

2.To study the applicability of using Voice Thread in developing the speaking skills of other EFL students at different stages (i.e., primary and secondary stage).

3. To test the effectiveness of Voice Thread in developing the different language skills. 
4. To test the effectiveness of Voice Thread in developing other thinking skills.

\section{References:}

Aliakbari, M., \& Jamalvandi, B. (2010). The impact of role play on fostering EFL learners' speaking ability: A task-based approach. Journal of PanPacific Association of Applied Linguistics, 14(1), 15-29.

Aljumah, F. (2011). Developing Saudi EFL students' oral skills: An integrative approach. English Language Teaching, 4(3), 84.

Asgharheidari, F., \& Tahriri, A. (2015). A Survey of EFL Teachers' Attitudes towards Critical Thinking Instruction. Journal of Language Teaching and Research, 6(2), 388-396.

Ataeifar, F., \& Bagheri, M. S. (2017). An Evaluation of Oral Interview and Voice thread as Elicitation Techniques to Assess EFL Learners' Speaking Skill. Journal of Applied Linguistics and Language Research, 4(4), 1-12

Augustsson, G. (2010). Web 2.0, pedagogical support for reflexive and emotional social interaction among Swedish students. The Internet and Higher Education, 13(4), 197205.

Blomberg, G. (2013). Vocabulary discourse: Developing meaning through" VoiceThread" publication. Retrieved November 2017 from http://fordham.bepress.com/diss ertations/AAI3560808

Boonkit, K. (2010). Enhancing the development of speaking skills for non-native speakers of English. Procedia-Social and Behavioral Sciences, 2(2), 1305-1309.

Brown, H. (2004). Some practical thoughts about studentssensitive critical pedagogy. The Language Teacher, 28(7), 2327.

Chan, M., \& Pallapu, P. (2012). An exploratory study on the use of VoiceThread in a business policy course. Journal of Online Learning and Teaching, 8(3), 223-237.

Diyyab, E., Abdel-Haq, E., \& Aly, M. A. (2013). Using a MultimediaBased Program for Developing Student Teachers' EFL Speaking Fluency Skills. Retrieved from ERIC database. (ED539987)

Dunn, M. G. (2012). The Effect of VoiceThread Integration on High School Students' Anxiety And Oral Proficiency In The Foreign Language Classroom (Doctoral dissertation, Liberty University).

Ghoneim, N. M. M., \& Abdelsalam, H. E. (2016 ) Using Voicethread to Develop EFL pre-service teachers' speaking. International Journal of English Language Teaching. 4(6),13-31

Facione, P. (1990). Critical Thinking: A Statement of Expert 
Consensus for Purposes of Educational Assessment and Instruction. Research Findings and Recommendations. The Delphi Report. Milbrae, CA: California Academic Press.

Herlihy, D. \& Pottage, Z. (2013). Formative assessment in a Web 2.0 environment: Impact on motivation and outcomes. Research Notes, 53, 9-17

Kalelioğlu, F., \& Gülbahar, Y. (2014). The Effect of Instructional Techniques on Critical Thinking and Critical Thinking Dispositions in Online Discussion. Educational Technology \& Society, 17 (1), 248-258.

Kidd, T \& Chen, I. (eds.) (2009). Wired for learning: an educator's guide to web 2.0. Information Age Publishing Inc. USA.

Lepore, C. E. (2014). Developing pronunciation skills at the Introductory. (Doctoral dissertation, The University of Alabama TUSCALOOSA).

Lipman, M. (2003). Thinking in education. Cambridge University Press.

McCormack, V. (2010). Increasing teacher candidate responses through the application of VoiceThread. International Journal of Arts and Sciences, 3(11), 160-165.

Muttaqin., W., (2014.) Using voicethread to give individualized feedback in teaching speaking. International Conference of Nepal English Language Teachers'Association NELTA. Retrieved from www.academia.edu

Oradee, T. (2012). Developing Speaking Skills Using Three Communicative Activities (Discussion, Problem-Solving, and Role-Playing). International Journal of Social Science and Humanity, 2(6), 533-535.

Pacansky-Brock, M. (2015). Evaluating the effects of an ebook to support faculty who teach with VoiceThread: An action research study. (Doctoral dissertation, Capella University). Retrieved from ProQuest Dissertations and Theses. (Order No. 3718013)

Pop, A., Tomuletiu, E. A., \& David, D. (2011). EFL speaking communication with asynchronous voice tools for adult students. Procedia-Social and Behavioral Sciences, 15, 1199-1203.

Richards, J. (2008). Teaching Listening and Speaking. Cambridge University Press.

Shirkhani, S. \& Fahim, M. (2011). Enhancing critical thinking in foreign language learners. Procedia - Social and Behavioral Sciences 29,111115.

Susanti, A. (2007). Using Role play in teaching speaking: a pre experimental study at Islamic 
junior high school. Retrieved from

http://repository.uinjkt.ac.id/dsp ace/handle/123456789/18390

Taddei, L., \& Budhai, S. (2015). Using Voice-Recorded Reflections to Increase Cognitive Presence in Hybrid Courses. Journal of Digital
Learning in Teacher Education, 32(1), 38-46.

Yusuf, F., \& Adeoye, E. (2012). Developing Critical Thinking and Communication Skills in Students: Implications for Practice in Education. African Research Review, 6(1), 311324. 